\title{
Democratic Education through the Eyes of the Poor: Appraising the Post-Apartheid Experience
}

\author{
Vuyisile Msila \\ College of Education, University of South Africa, UNISA, ooo3, South Africa \\ *Corresponding Author: msilavt@unisa.ac.za
}

Copyright (C) 2013 Horizon Research Publishing All rights reserved.

\begin{abstract}
Arguably, one of the major achievements in the 1990s in South Africa was the final toppling of apartheid government and the triumph of democracy over the unjust and unequal past legislation. Since then schools are some of the institutions that have infused democracy ideals into their policies, curriculum and other aspects of school life. The post-apartheid education was formulated with direct links to the Constitution of the Republic. "Education is the key because it empowers us to exercise our democratic rights, and shape our destiny, by giving us the tools to participate in public life, to think critically, and to act responsibly" [1]. The post-apartheid education policy proclaimed in 1997 also declared that education and the curriculum in particular have an important role to play in realizing the democratic aims of the Constitution. Furthermore, the curriculum aimed to develop the full potential of learners as citizens of a democratic South Africa. The post-apartheid education in South Africa is based on noble values born out of the years of struggle. Education is perceived as a perfect tool to realize the ideals of democracy because it would lead people to be critical citizens, hence they would play a pivotal role in the transformation of society. Yet, there are paradoxes in a democratic society and this article explores some of them.
\end{abstract}

Keywords Poverty, Equal Education, Values, Opportunities, Education Policy, Class

\section{Introduction: Living the Past?}

Clad in their school uniforms Sihle and Zola emerge from the Ramaphosa informal settlement in Port Elizabeth on their way to school. The two girls are 13 and 14 years old respectively and they live in the same shack with their two mothers who are sisters. Zola will catch two busses before she reaches her school in Newton Park in the city. Sihle will walk 12 kilometers to her own (historically black) African school in the township. Years after the dismantling of the apartheid policy, historically black African schools are still serving black African families only. Yet, Zola's hard working mother is one of the working class mothers who are spending their last cents to make use of the opportunity to bus their children to better resourced and "more effective" schools outside the historically black African areas or townships. Democracy has accorded this opportunity to many black African parents who want to exercise the choice of choosing schools outside the townships. As the two girls stride forward, they soon split into different directions at the crossroads; Sihle joins a line of languid learners sauntering on the dusty road to Ndaba High School ${ }^{1}$ and many other schools around the township, while Zola turns her back to her cousin as she joins the bus queue of sprightly looking learners going to the city. The two will return home in the late afternoon, relating two stories of vastly different experiences. Their daily metaphorical split at the crossroads can be perceived as a portentous break that will be significant in their futures after the completion of their high school careers.

Apartheid failed to address the challenges of difference among schools. Motala and Pampallis [2] contend that learners under the apartheid education system were faced with inequality regarding access to education with poor provision of resources for most learners. However, recently, Fleisch [3] argues that South Africa has two education systems, the first has better resources in former white schools with better performing learners. The second one is comprised of poorly resourced schools, mostly in historically black African schools. Christie [4] also highlights the need to recognize the differences between poor and affluent schools. Furthermore, she states that schools in poor and disadvantaged communities are seldom well resourced as schools in wealthier areas. Davies [5] posits that there is much research which suggests that, years after democratic rule in South Africa, there are still huge gaps between the rich and the poor. "Certainly in 1994 there were massive disparities in this regard, which meant then as it does now - that there were in the wider society some "haves" and numerous "have-nots": there are various pieces of research dealing with the huge gaps existing at that time

not the school's real name 
between the various population groups" [5].

This article investigates the struggle for democratic education in South Africa as it reviews relevant literature that explores how democracy in education serves the majority of (black) South Africans. After two decades of freedom it is interesting to examine how issues such as class, socio-economic status and race impact on the black Africans' education. The article explores a few of these aspects which include post-apartheid educational opportunities, Fanon's view of post-independence politics, as well as Foucault and issues of power before the conclusion which links these to poverty in South Africa.

\section{Post-Apartheid Opportunities and the Poor: the Great Paradox?}

Reimers [6] points out that education and poverty are related in multiple ways. He asserts that the poverty of the households in which children are raised with low levels of nutrition, health and cultural capital causes children to have low educational opportunities. "In turn, as the children of the poor develop insufficient skills and knowledge to gain access to high productivity jobs and to transfer cultural capital directly to their children, their low education levels 'cause' poverty to be reproduced between generations" [6]. Jenck [7] highlights the importance of identifying humane justice and socio-economic inequality as he stresses why these are necessary in society today. Social scientists such as Giroux and Bourdieu would argue that capitalist societies tend to reproduce themselves when it comes to schools. Learners encounter a system that has authoritarian teachers and subordinate working class children find themselves having to subscribe to the dominant classes in society. The new human rights culture in South Africa wants to address this status quo; poor black African learners crave for equal opportunities from the system. Many poor people, though, will argue that the current system still short-changes them. These learners are still trapped in under-resourced schools situated in poor neighborhoods with teachers who are under-prepared. The human rights culture should address these situations to attain humane justice and effective democracy. Jenck [7] states that schools have an obligation to compensate poor children because their environments are by-products of the society's collective commitment to unequal socio-economic rewards. This presupposes that, if schools cannot neutralize these inequalities, then they are unjust and undemocratic. It was for these reasons that the policy of post-apartheid education wanted to address the issue of democratic values.

The post-apartheid education policy is intent on ensuring that South African education policy is based on fairness and the democratic Constitution of the Republic. The Report of the Working Group on Values in Education, for example, highlighted six qualities that the education system should promote: equity, tolerance, multilingualism, openness, accountability and social honour [1]. This document further explicates values such as democracy, social justice, equality, non-racialism and non-sexism, ubuntu, the rule of law and respect in a way that suggests how the Constitution can be taught as part of the curriculum. It is also generally acknowledged that classroom management is critically affected by a number of issues when it comes to the teaching of the curriculum:

\section{Questions and issues regarding pedagogy and curriculum intersect with the political, moral, economic and cultural domains of society. Educational choices frequently respond to, and help reinforce, some set of values, priorities, and perspectives that have the effect of furthering some interests while hampering others. Teachers as a result confront several difficult, complex issues: What values should guide the establishment of some kind of classroom climate? [8]}

The post-apartheid curriculum embraced in South Africa was conceptualized to (among others), result in nation building. It is informed by the Constitution of the Republic which makes up the "South African idea of molding a people from diverse origins, cultural practices, languages into one, within a framework democratic in character, that can absorb, accommodate and mediate conflicts and adversarial interests without oppression and injustice" [1]. Wood [9] contends that the curriculum should be structured to embrace the values of democratic life. Furthermore, Wood avers that these include the essential values of equality, liberty and community. The Report of the Working Group on Values [1] asserts that there are two primary ways in which the human rights culture can establish mutual respect between teachers and learners; the first has to do with what is taught and the second has to do with how this is taught. Arguably, the poor are beginning to experience that the system is failing them in a number of instances. The survival in the society is usually for those who have power; those without power, such as the poor, usually feel deprived in a number of ways. Frantz Fanon has discussed these themes in his work.

\section{Deprivation and Power: Reading Fanon}

In his book, Black Skins, White Masks [10] Fanon explicates the sense of dependency, helplessness and inadequacy that black Africans experience in a "white world". Fanon, a qualified psychiatrist, uses psychoanalysis to explain the black behaviour after the loss of culture. Amongst others, Fanon raises an argument that it is because of language that people in former colonized states experience marginalization, pathologization and servitude. He says that language is an index of power imbalance and cultural difference. Furthermore, Fanon [11] contends that 
colonialism not only physically disarms the colonized subject, but it also robs her of a pre-colonial cultural heritage. The deprivation of language and culture enabled the colonized to assume an identity of being the other. As traditional culture dissipated among the indigenes, the creation of otherness seeped through. Black Africans became poorer and poorer and regarded the colonizer as the provider. There developed a schism between the black African and the Westerner:

The creation of otherness (also called
othering) consists of applying a principle
that allows individuals to be classified into
two hierarchical groups: them and us. The
out-group is only coherent as a group as a
result of its opposition to the in-group and
its lack of identity. This lack is based on
stereotypes that are largely stigmatizing
and obviously simplistic. The in-group
constructs one or more others, setting itself
apart and giving itself an identity. [12]

The politics of colonialism and racism entrenched this otherness. The black African was marginalized by the Western society. The poor found themselves at the peripheral of the society, more so for those who lived in the rural areas, far from the cities. The latter is what Fanon refers to as the "damned of the earth" (Les damnes) [13]. The poor were condemned by the white minority government during the apartheid years. Today, however, some argue that, under black African rule, the poor continue to be the biggest losers because many cannot afford homes, electricity and running water [14]. Fanon [11] writes:

\section{The people who for years on end have seen this leader and heard him speak, who from a distance in a kind of dream have followed his contests with the colonial power, spontaneously put their trust in this patriot. Before independence, the leader generally embodies the aspirations of the people for independence, political liberty and national dignity. But as soon as independence is declared, far from embodying in concrete form the needs of the people in what touches bread, land and the restoration of the country to the sacred hands of the people, the leader will reveal his inner purpose: to become the general president of that company of profiteers impatient for their returns which constitutes the national bourgeoisie.}

Research continues to reflect that in South Africa the poor have not decreased in numbers since 1996. In 2001, an HSRC study discovered that those households living in poverty have sunk deeper into poverty and the gap between the rich and the poor has widened. In $200157 \%$ of the people were living below the poverty income line, and this was unchanged since 1996 [15]. Naidoo [16] also writes about the widening gap citing Natrass who identifies three main classes in post-apartheid South Africa. These are (i) the extremely wealthy and multiracial elite; (ii) the intermediate middle class group incorporating professionals and the organized working class and (iii) the marginalized including the lowly paid farm and domestic workers and the unemployed. Szczepanksky [17] highlights how the overall distribution of wealth in South Africa is still divided along racial lines and how times are becoming harder for the poorest of the poor. Furthermore, he points out that the unemployment rate for black South Africans is $41.2 \%$ while among white South Africans it is 5.1\%. Even more shocking facts are that about $71 \%$ of white South Africans have at least high school education whilst only $22 \%$ of black Africans have finished high school. Among the crucial questions to be posed will be to ask, how is democracy redeeming the poor.

\section{Democracy and the Poor}

After the attainment of democracy in 1994, the South African government was intent on continuing to combat many social ills and injustices. Among these was poverty. The apartheid policy left many vestiges of inequalities in society, though, and as the discussion above shows, years after freedom, inequality continues to be experienced in the society. Inequality is also demonstrated through the lack of access to natural resources; a dual health system and other socio-economic dimensions [18]. Despite these inequalities, South Africa is usually said to have one of the best democracies in the world. Ross [19] argues that there is evidence in research that democracies do a better job than non-democracies to improve the welfare of the poor. Furthermore, Ross argues that research shows that democracies fund public services at a higher level than non-democracies; however, it is not obvious that these monies reach the poor. Ross also raises a pertinent question probing why, if democracies spend more money on public service, they fail to deliver better results. He answers this by contending that "perhaps democracies subsidize the budgets of middle and upper income groups who can afford to buy food and health services privately, but not the poor, who find food and health services unaffordable" [19]. The South African government is doing so much to bring better life to South Africans although the number of the poor does not seem to dwindle. Many schools have been erected, houses have been built mainly for the low earners and sanitation is being introduced in distant rural areas, but there is still a high rate of unemployment. High unemployment rates lead to poverty

Varshney [20] points out that democracy in developing countries has had an unimpressive record at poverty alleviation; that democracies have been sluggish in combating poverty. Seekings [21] also postulates that democratic South Africa was born amidst high hopes for reduction of poverty and inequality. However, Seekings [21] 
like others cited above, maintains that reality has been disappointing: there is persistent unemployment, an unequal education system and a social safety net that is unusually widespread but nonetheless with large holes. He declares:

Democratization was therefore
accompanied by high hopes that income,
poverty and inequality would be reduced.
The poor were to be enfranchised, the
pro-poor and pro-black African National
Congress (ANC) would be elected into
office and public policies and private
practices would be deracialized. The ANC
promised 'a better life for all' in its 1994
election campaign. Its election
manifesto-the Reconstruction and
Development Programme (RDP) -
promised that 'attacking poverty and
deprivation' would be 'the first priority of
the democratic government'. [21]

Years after the 1994 freedom, incessant delivery protests from the poor continue. The poor protest for housing, for food and for employment. The former president of South Africa, Thabo Mbeki, once referred to South Africa as a two-nation society, where one nation is rich and has the opportunities, the other not. This is similar to Fleisch's contention about education above. "One of these nations is white, relatively prosperous, regardless of gender or geographic dispersal. The second and larger nation...is black and poor, with the worst-affected being women in the rural areas, the black rural population in general, and the disabled" [21]). Despite these, many would still argue that education is the best tool that can level the playing fields for the poor. Some critics would even argue that there needs to be more educational opportunities for the black Africans.

\section{Educational Opportunities: Failing of the Poor?}

The struggle for a free education system in South Africa was always connected with the broader struggle for democratic rights and the ending of apartheid [22]. During the struggle against apartheid education, many political activists were calling for a free, compulsory, non-racial democratic system of education relevant to the establishment of a unitary democratic South Africa [23]. The concept of a People's education was coined during this time. People's education was perceived as an alternative system to replace apartheid education. Based on non-racial and non-sexist principles, this system was supposed to liberate the South Africans' minds: free them from apartheid ideology thinking. Yet some authors argue that it was not always easy to understand who was embodied by the concept, "people". The classes which comprise the people were never clearly spelt out; the contradictions between them were not worked out [22]. However, to many activists in the liberation struggle the people referred to those who were opposing apartheid, black and white. The people would include the rich and poor. People's education, then, was being contemplated as a system that would replace apartheid education, and it was also expected to include "all sections of our people", enabling students, parents, teachers and workers to participate in the formulation of a new education system [23]. The people wanted a system that would promote the values of democracy and active participation. Hartshorne [23] lists educational objectives of what "the people" wanted their post-apartheid education to have:

- To eliminate illiteracy, ignorance, capitalist norms of competition, individualism, stunted intellectual development and exploitation.

- To enable "the oppressed to understand the evils of the apartheid system" and to prepare them for participation in a non-racial democratic system.

- To equip and train "all sectors of our people to participate actively and creatively in the struggle to attain people's power in order to establish a non-racial, democratic South Africa.

The idealistic plan of a People's education system shows how the stakeholders then sought to involve all the people to play a role in implementing an alternative system to apartheid education. The above also illustrates the political nature of education and how the poor get entangled in this game. After two decades of freedom the South African schools continue to be crowded with a myriad of political problems. Labaree [24] contends that schools occupy an awkward position, at the intersection between what people hope society will become and what they think it really is; between political ideals and economic realities. Furthermore, he states that the central problems with education are not pedagogical, organizational, social or cultural in nature but are fundamentally political. The poor do not have a voice, they do not have power to influence systems and this is very political in nature. Schools sort the poor due to societal and political pressures. De Lany [25] asserts that schools are continually scrambling for order in a rather disorderly world. Economically able black African parents in South Africa choose effective historically white schools situated outside the townships or historically black areas. The latter is arguably one of the positive aspects of post-apartheid education policy; all parents are able to choose schools.

Many writers, though, disagree with the above assertions. They contend that the exercise of school choice widens the gap between the rich and the poor [26]; [27]; [28], [29]; [30]. Kelly [26] also points out that school choice favors the wealthy and better informed to the disadvantage of the poor. The poor parents in South Africa are still trapped in underperforming township schools with few or no physical resources and underprepared teachers. None of these 
historically black African schools have attracted any white families after the demise of the apartheid policy. District offices that serve the disadvantaged areas continue to struggle in finding ways of educating poor children who come to school without the advantages of their more affluent counterparts [35]. South African schools are not different from others around the world. The schools serve parents differently because power relationships vary considerably with the social class and racial background of the parents [32]. Even dealing with teachers, poor parents are at a disadvantage; they can find themselves being used as pawns in the battles of larger political forces within the education setup [32]. These arguments show that schools can be a disservice to the poor families. .

Nieuwenhuis [33] cites Schaar who defines equality as one of those political symbols into which mankind has poured the deepest urgings of their hearts. Every strong held theory of equality is at once a psychology, an ethic, a theory of social relations and a vision of the good society. The quality of schooling is questioned by similar reports. The quality of schooling available to different learners is crucial to their future chances of occupational mobility [30]. Furthermore, Hurn [34] whose research on the United States of America's (USA) education is significant for South Africa commented on the USA's education of the 1960s by stating:

Poor students were severely handicapped by
inferior schools, black students by the fact that
most of the schools they attended were quite
simply, bad schools. Black students attended, for
the most part, segregated institutions...Inferior
schooling compounded the initial handicaps of
these students and led directly to the
perpetuation of poverty and inequality in the
next generation.

The parallels with apartheid South Africa are striking. Learners from historically black African schools were destined to a condemned future. The learners in these schools were struggling when searching for future job opportunities. Therefore, Bantu Education for black Africans was indeed able to put them in a state of docility and fewer opportunities. Apartheid education was based on injustice and segregation, both aspects that are an antithesis of democracy. The current post-apartheid system of education is built upon the foundations of democracy as it supports egalitarian and democratic ideals. As pointed out in the introduction, the policy of education is based on the democratic Constitution. However, in reality the schism exists between schools, with rural schools and historically black African schools having the largest number of low performing schools. Fataar [35] writes of how township schools intensify social reproduction as they fail the learners. He argues:

Unlike those children who migrate to city schools. township school children are stuck in the township, and the schools play a deficit role, one of lack, in this reproduction process. It is what these schools are not doing that defines their subjectivity as poorly performing schools, unable to make the discourses of the city beyond the township available to their students.

Children from the township schools replicate the societal inequalities. Lareau and Horvat [36] state that Bourdieu's main insight on educational inequality is that learners with more valuable social and cultural capital fare better in schools than their peers with less valuable social and cultural capital. Hurn [34] underscores a radical paradigm theory whose proponents argue that schools are institutions that perpetuate inequality and convince lower class groups of their inferiority. "In the radical paradigm what is important about schooling is not the cognitive and intellectual skills schools teach but the class-related values and attitudes that they reinforce" [30]. Some poor children attending many township schools know they will never make it. Schools reinforce this inequality and teachers in the majority of these schools are partly to blame as they neither do not display any commitment to professionalism. Annually, when matric ${ }^{2}$ (grade 12) results are announced every January, the inequality of schooling is glaring as township schools languish at the bottom of the list of secondary schools. Some of these aspects are much influenced by funding. Arguably, it matters how much the school has in its coffers as much as does the quality of its human resources. Below, the discussion focuses on the funding of schools as well as opportunities.

\section{Funding of schools and opportunities}

The post-apartheid government has from its inception tried to address challenges linked to funding. For example, one of the first papers to address funding was the paper entitled, Education and Training in a Democratic South Africa First Steps to develop a new system [37]. This paper contends that to develop a new system:

The basis of financial allocation to
different categories of state and
state-aided schools must be equitable and
transparent, aimed at eliminating
historical disparities based on race and
religion ensuring an acceptable quality of
education.
In particular, an equitable staff provision
scale or scales must be phased in at state
and state-aided schools as rapidly as

${ }^{2}$ matric is grade 12 , the last class in secondary schools. Secondary schools' performance in South Africa is usually gauged by analyzing each school's matric results. 


\begin{abstract}
possible, in full consultation with the representative organizations of the teaching profession. The question of eligibility of independent schools to state subsidies must be determined using clear and equitable criteria based on possible interest, and the observances of constitutional guarantee.
\end{abstract}

Equity, efficiency and quality are cornerstones of this report. Moreover, the nature of the post-apartheid education policy itself is established in such a way that it is unequivocal on the value of democratic right and education. The Schools' Act of South Africa, Act of 1996 also states that learners cannot be barred from education because they do not have money. Opponents of school fees, for example, maintain that school fees act as a barrier to education for poor children [38]. The EQUIP 2 documents cite experts who argue that school fees marginalize already vulnerable segments of the population and reinforce existing inequalities. The likelihood of the learners attaining a certain stage of education becomes highly correlated with their families' income levels.

Rich schools generate money through school fees whilst poor schools struggle to get the money from their indigent parents. The payment of school fees has an impact on enrolment patterns. Chisholm [39] contends that parents who accept the need to pay fees tend to sort themselves into schools partly in line with the fees that they are willing and able to pay. In schools serving richer communities, both the level of fees and the collection rate are generally much higher than in schools serving the poor. Affluent schools have an advantage of being better resourced than those schools serving the poor and the latter are usually situated in historically black areas. Soliciting school funds from the parents enhances the gap between the haves and have nots for poor parents would choose schools that would be amenable with their pockets or wages. A range of survey data has been collected to better understand the socio-economic circumstances of children in South Africa. Children are disproportionately represented among the poor. Using different poverty lines and data sets, various studies estimate that between 58 and $75 \%$ of South African children live below the poverty line. Poverty is concentrated among black African households: $52 \%$ of black people, $17 \%$ of Coloreds, and less than 5 per cent of Indians and whites are poor [39].

Currently, schools are divided according to quintiles considering the socio-economic status of the parents and the community. Some schools also have been declared no-fee schools. The majority of former white schools are declared as highest quintile schools (quintile 5) because the community and the parents can afford to pay school fees and have sufficient resources, both physical and human. Many historically black African schools are declared low quintile schools classified as quintile 1 or quintile 2 . However, there is constant disquiet as stakeholders state that even the budget allocated to the low quintile schools is not enough. Many poor and disadvantaged schools that belong to the low quintiles do not enforce the payment of school fees but they usually face challenges from shortage of funds. The lack of funds is always a challenge to the smooth running of schools. The effects of poverty on education should never be underestimated for the resources that schools have play some role in the quality of education delivered. The more resourced the schools the more powerful they become.

\section{Power and Education}

In his works Michel Foucault explores the aspects of power in a variety of ways. In fact, Foucault argues that power is ubiquitous, that it comes from everywhere [40]. He posits that power is exercised through a net-like organization and that individuals in organizations circulate between its threads. Schools are then institutions that will be affected by this power, Furthermore, Foucault [41] posits that educational institutions are "polymorphous" and that they combine economic, political, judicial and epistemological relations of power, Foucault opines that in schools there are orders and rules which, he and that one would argues, frequently disadvantage the poor. Moreover, Foucault claims that schools classify and sort learners according to their abilities. He also poses the question: "why must one punish and reward in order to teach something to someone?" [41]. In schools, learners learn about social control; the hidden curriculum of relationships in the school informs the learners how they need to behave in society. In his earlier works, Foucault looked at the purposes of societal institutions such as the prison, the clinic and the mental asylum and explored themes of power and knowledge in education.

The sharing of power needs to move beyond the political rhetoric. Gibson [42] cites Fanon's work when he states that Fanon's visionary critique of post-colonial elite mapped out a "living politics" based on a decentralized and democratic form of self-governing which opens new spaces for the politics of the excluded from the ground up. Furthermore, Gibson [42] avers that one can understand Fanon's project by perceiving it as building counter-hegemony from below that opens up spaces that fundamentally change the political status quo and contest the moral and intellectual leadership of the ruling elites. There needs to be more voice accorded the poor if we can truly talk of democratization of education. Hunt [39] also writes about how power in schools affects the stakeholders, including learners and their families. Aspects such as housing and socio-economic status determine power in society.

There is power which educators do not have and this is the necessary power to influence policies. Those who personify this power usually trivialize the little power they have. Mills [40] mentions the influence of the power elite in 
determining policy. Theodolou [41] highlights the elite theory which policy experts like Aldrich and Wotherspoon [40] as well as Gibson [42] state that public policy is not determined by the masses but by a minority who have political and economic power. The latter group is defined as a conglomeration of the higher circles belonging to the top in the social stratum. They know one another and in making decisions they consider one another. Unfortunately, many educators do not belong here. They cannot be part of the game because those who belong in these higher circles most of the time set the rules.

Many teachers in schools frequently carp because of unfair competition between themselves and the rest of education's stakeholders in policymaking. They "know" that they are experts in their classrooms but the playing fields do not offer opportunities for a fair game. I have to quickly point out that it would be foolish to think of an utopian state where all the players are at the same level. Gibson [42] states that democratic and pluralist theory could not have gained the level of ascendancy if it had not been based on permitting various groups and associations to organize openly and freely. However, the key phrase here is "organizing freely and openly." Teachers do not seem to enjoy these luxuries. Having to meet deadlines set by bureaucratic systems manned by their administrators, they are relieved of freedom. At least in all teams, in all matches, players start games on an equal level and in this context the good players will excel. The teachers, however, start the game on an unequal level.

The inequality that exists among stakeholders in educational planning displays that there are many paradoxes regarding teachers' role. While many might feel that the teachers have no role to play in educational policy making, there are those (including educators), who believe that educational change cannot be complete without teacher input. The discussion will now focus on the paradox of educational policy. Most discussions above delineate the perplexity of educational policy especially about the poor as actors in policy design and implementation. Much research has shown that teachers' inadequate knowledge justifies their absence in policy design. Boyd [47] cites Lindblom who wrote about partisan analysis, which is a policy where one group finds a way in which a policy can serve the values of another group to whom persuasion is intended. One might argue that the indigent are victims of this partisan analysis. Research and analysis of policy is very political and partisan analysis is one of the factors that contributes to contradictions in educational policies.

\section{Concluding Remarks: Reproduction and the Scourge of Poor Schools}

Perhaps the most important challenge in post-apartheid South Africa is to see democracy become a reality for schools, although others will wonder whether this is a possible ideal to attain as democracy's foe appears to be democracy itself. As we conclude the arguments it is apt to look at how reproduction presents an antithesis to democratic education. We started this article by looking at two cousins going to school; one at a historically black African school and the other a historically white school. As they go to school they separate as they traverse different paths, paths that will certainly separate them for the legacy of their schools is likely to divide them eternally. Their schools continue to affirm and perpetuate the society's perceptions. Children from township schools are less likely to succeed at the rate of learners from historically white schools. We know that there are many failing historically white schools but research shows that most dysfunctional schools are in the townships. Parents with no power are usually in the township schools. Families who are trapped in an economic quagmire are also in the township and usually they pass their circumstances on to their children.

Baker [48] poses a pertinent question when he asks, what are schools for? He also argues that schools are frequently confused about their role for a number of stakeholders, including opposition parties, trade unions, experts and other pressure groups are all pushing their vision of what schools are for [48]. The latter is a similar argument to that advanced by [28] in earlier paragraphs. Interestingly, Baker's answer to the question he posed is that the answer will depend on who wins the struggle for power over schools. Parents and families with no economic and political power are unlikely to win power over schools. The middle class dominate schools and schools implement their agenda. According to [34] the liberal and progressive interpretation of schooling will mean that schools should teach the dominant privileged values of technocratic or capitalist society and keep the poor in their place. Yet the radical paradigm reflects pessimism with regard to the current schooling system in the sense that the current society is not only repressive and inhumane but liberal social reform cannot bring about fundamental change [34].

Every time when Sihle and Zola go back to their Ramaphosa informal settlement home, they will see that their schools do not appear equal. Zola's city school is likely to be well equipped with effective physical and human resources, while many township schools continue to struggle in various ways although there might be a glimmer of hope from society that education and schooling have the potential to free the citizens. All countries emerging from autocratic government dispensations will perceive democracy as the redeemer that would result in a just society. Democracy is usually perceived as a panacea for many social ills and unjust education is among these. However, Chubb and Moe [49] state that there are no panaceas in social policy. Plank and Boyd [50] support the latter although they put it differently. They stated that democratic governance is not a panacea for the problems of educational systems. However, Plank [50] also recognize the importance of democracy's role. They cite Winston Churchill who noted that the worst persuasive argument in 
favor of upholding democratic institutions is that alternative institutional arrangements are even worse. Yet the paradoxes of democracy's role are very pronounced here. Despite a decade of democracy, many people still suffer from the effects of a crippling history and can hardly enjoy the benefits of freedom and democracy. However, many perceptive minds would still argue that it should not be democracy that is blamed here but the people who manipulate it.

\section{REFERENCES}

[1] Department of Education (DoE), Manifesto on Values, Education and Democracy, Government Printer, Pretoria, 2001.

[2] E. Motala, J. Pampallis, Educational Law and Policy in Post apartheid South Africa. In E. Motala, J. Pompallis (eds.) The State, Education and Equity in Post-Apartheid South Africa: The Impact of state policies, Antony Rowe, Wiltshire, 2002.

[3] B.D. Fleisch, Primary Education in Crisis. Why South African school children underachieve in Reading and Maths? Juta, Cape Town, 2008.

[4] P. Christie, Changing schools in South Africa: Opening the doors of learning. Heinemann, Johannesburg, 2008.

[5] H. Davies, Some aspects of equity in the funding of public schools in South Africa, Perspectives in Education, Vol 22, No. 3, 109-124.

[6] F. Reimers, F. Educational opportunities for low-income families in Latin America. Prospects, Vol XXIX, No. 4, 536-549.

[7] C. Jencks, Does inequality matter? Daedelus, Winter, 49-65.

[8] L.E. Beyer, Schooling for democracy: What kind? In L.E. Beyer, M.W. Apple, (eds). The curriculum: Problems, Politics and Possibilities. State University of New York Press, New York, 1998.

[9] G.H. Wood, Democracy and Education. In L.E. Beyer, M.W. Apple, (Eds). The curriculum: Problems, Politics and Possibilities. State University of New York Press, New York, 1998.

[10] F. Fanon, Black Skins, White Masks (Translated by C.L. Markmann), Grove Press, New York, 1967.

[11] F. Fanon, The Wretched of the Earth (translated by C. Farrington), Grove Press, New York, 2001.

[12] J.F. Staszak, Other/otherness, Online available from http://www.inige.ch/ses/geo.

[13] F. Fanon, The Wretched of the Earth (tr by Constance Farrington and Preface by Jean Paul Sartre), Grove Press, New York, 1968.

[14] D. McDonald, J. Pape, Cost recovery and the crisis of service delivery in South Africa, HSRC, Cape Town, 2002.

[15] HSRC Fact Sheet- Poverty in South Africa. HSRC. The Author, Pretoria, 2004.
[16] [16] K. Naidoo, The 'politics of poverty' in a post-apartheid South African metropolis. African Sociological Review Vol. 2, 55-78.

[17] K. Szczepansky, Poverty and inequality in South Africa, Online from http://www. Helium.com/items/1002622-poverty-and-inequality.

[18] J.D. Triegaardt, Poverty and inequality in South Africa: Policy considerations in an emerging democracy. Paper presented the annual Association of South African Social Work education Institutions (ASASWEI) Conference organised by the University of Venda, 18-20 September, 2006.

[19] M. Ross, Is democracy good for the poor? American Journal of Political Science, Vol. 50, No, 4, 860-874.

[20] A. Varshney, Democracy and Poverty. Paper prepared for the Conference on World Development Report 2000. Caste Donnington, England. August 15-16 1999.

[21] J. Seekings, Poverty and inequality after apartheid. Paper prepared for the second 'After Apartheid Conference. Yale, 27-28 April 2007.

[22] G. Mashamba, A conceptual critique of the people's Education Discourse. Review of African Political Economy Vol. 48, 50-65

[23] K. Hartshorne, INSET in South Africa: HSRC Report 1985, The Urban Foundation, Bloemfontein, 1986

[24] D. Labaree, Public goods: The American struggle over educational goals, American Educational research Journal, Vol. 34, No. 1, 39-81.

[25] B. DeLany, The Micro-politics of School, Teacher, and Student Failure: Managing Turbulence, In B.M. Franklin, (Ed). When Children Don't Learn: Student Failure and the Culture of Teaching. Teachers College, Columbia, 1998.

[26] A. Kelly, School choice and the student wellbeing: opportunity capability in education: Reviewing the research and adapting Sen's theory of capability to school choice. Palgrave Macmillan, London, 2007.

[27] J. O'Neil, New Options, Old Concerns, Educational Leadership, Vol. 54, 6-8.

[28] R. Bilfalco, H.F. Ladd, S. Ross, The Effects of Public School Choice on those left behind: Evidence from Durham, NC. The Peabody Journal of education, Vol. 84, No. 2.

[29] N.L. Gray, School Choice and Achievement: The Ohio Charter School Experience. Cato Journal, Vol. 32, No. 3, 557-579.

[30] P. Musset, School Choice and Equity: Current Policies in OECD Countries and a Literature Review, OECD, No. 66.

[31] R.G. Corwin, E.J. Schneider, The school choice hoax. Praeger, London, 2005.

[32] D.J. McGrath, P.J. Kuriloff, "They're going to tear the doors off this place": Upper-middle-class parent school involvement and the educational opportunities of other people's children. Educational Policy, Vol. 13, No. 5, 603-629.

[33] J. Nieuwenhuis, from equality of opportunity to equality of treatment as a value-based concern in education. 
Perspectives in Education, Vol. 23, No. 3, 55-64.

[34] C.J. Hurn, The limits of schooling: an introduction to the sociology of education, Allyn and Bacon, Boston, 1978.

[35] A. Fataar, Schooling subjectivities across the post-apartheid city. Africa Education Review, Vol. 6, No.1, 1-18.

[36] A. Lareau, E.M. Horvat, Moments of social inclusion and exclusion race, class and cultural capital in family-school relationships, Sociology of Education, Vol. 72, 37-53.

[37] Department of Education, Education and Training in a Democratic South Africa First Steps, Notice 196of 1995, DoE, Pretoria, 1996.

[38] EQUIP 2. 2010. School fees in South Africa: Increasing quality or decreasing equality. USAID, Washington, 2010.

[39] L. Chisholm, Changing class: Education and Social Change in Post-apartheid South Africa, HSRC, Pretoria, 2004.

[40] R. Aldrich, G. Wotherspoon, Who's who in Contemporary Gay and Lesbian History: From World War II to the Present Day,

[41] M. Foucault, The subject and power. In J. Faubion, (Ed). Translated by R. Hurley. Power: The Essential Works of Michel Foucault, 1954-1984, New Press, New York, 2000.

[42] N. Gibson, Amandla is still Awethu: Fanonian Practices in post-apartheid South Africa, Online from http://abahlali.org/files/fanon.

[43] C. Hunt, Family links nurturing Program. Oxford Family Links, 2003.

[44] C.W. Mills, The power elite. In S.Z. Theodolou, M.A. Cahn, (Eds). Public Policy: the essential readings. Prentice Hall, Englewood Cliffs, 1995.

[45] S.Z. Theodolou, How public policy is made. In S.Z. Theodolou, M.A. Cahn, (Eds). Public Policy: the essential readings. Prentice Hall, Englewood Cliffs, 1995.

[46] R. Milliband, Imperfect competition. In S...Z. Theodolou, M.A. Cahn, (Eds). Public Policy: the essential readings. Prentice Hall, Englewood Cliffs, 1995.

[47] W.L. Boyd, Policy analysis, Educational policy, and Management, Longman, New York.

[48] M. Baker, Who rules our schools? Hodder \& Stoughton, London, 1994.

[49] J. Chubb, T. Moe, Politics, Markets and America's Schools, Brookings Institution, Washington DC, 1990.

[50] D.N. Plank, W.L. Boyd, Anti-politics, education, and institutional choice: the flight from democracy. American Educational Research Journal, Vol. 31 No. 2, 263-281. 